\title{
DEVELOPMENTS OF SPORTS LAW IN THE REPUBLIC OF SLOVENIA
}

\author{
UDK: 796/799; 34 (497.4) \\ DOI: $10.31141 /$ zrpfs.2020.57.136.287 \\ Izvorni znanstveni rad \\ Primljeno: 10. prosinca 2019.
}

\begin{abstract}
The authors addressed the topic of the development of sports law in the Republic of Slovenia, both from historical and analytical perspectives. A new Sports Act (ZŠpo-1) was recently adopted in Slovenia in order to replace a previous - and somewhat outdated - Sports Act (ZSpo). This framework act regulates basic requirements for the organisation and implementation of sports activities. The article includes a presentation of the most important changes that affect the organisation of sports in Slovenia. Other issues related to the area of sports law can generally be solved by applying general provisions (e.g. from Code of Obligations, Criminal Code and other fundamental acts). In addition to the historical development of Sports Act, the article also includes the analysis of some of the most important general acts that can be applied to sports-related issues.
\end{abstract}

Key words: sports law, organisation of sport activities, liability for sport injuries, doping, media rights

\section{INTRODUCTION}

Despite the fact that sport has always been a part of human life (Stanković, 2015 , p. 14), sports law, as a separate branch of law, has only recently begun to develop, but it did so at an incredible rate. Sports are tightly linked to the way of life in a certain historic period, and the first competitions promoted those skills and competences that were an integral, if not necessary, part of the everyday life. Thus, for example, hunting, horseback riding, archery, javelin, running, fighting and other similar activities were present both in the time of peace and during wars. They were indispensable for the development and continued existence of a community or society as well as an individual (Petrović, Doupona Topič \& Petrovič, 2006; Mikša, 2010).

1 Information about the authors: Suzana Kraljić (Maribor, Slovenia) - PhD. Associate Professor of Family, Succession and Medicine Law, Faculty of Law, University of Maribor, Slovenia, (Mladinska ulica 9, 2000 Maribor, Slovenia; e-mail: suzana.kraljic@um.si); Miha Šepec (Maribor, Slovenia) - PhD. Assistant Professor of Criminal Law, Faculty of Law, University of Maribor, Slovenia; (Mladinska ulica 9, 2000 Maribor, Slovenia; e-mail: miha.sepec@um.si). Katja Drnovšek (Maribor, Slovenia) - Assistant in Family and Succession Law and Philosophy and Theory of Law, Faculty of Law, University of Maribor, Slovenia (Mladinska ulica 9, 2000 Maribor, Slovenia; e-mail: katja.drnovsek@um.si). 
The origins of modern sport can be sought in England, in the first attempts to organise the exercise and training activities. The word for sport can be found in the English language as early as in the 17th century. The word sports is of Roman origin and originates from "disportare", which means "to cheer up" or "to have fun". Another meaning of the word sport is "to go out through the city gates," which probably refers to the fact that the Romans had their training grounds outside the city walls (Petrović, Doupona Topič \& Petrovič, 2006). On the other hand, the United States (US) can certainly claim the credit for the first beginnings of sports law, as they developed specific rules governing sports and sports activities quite early on. Sports play a special role in the US and, consequently, in the field of law, as it is associated with high financial returns (Nanev, 2013, pp. 167-187). On a global level, arguably the most important milestone in the development of organised sport is the year 1894, when Baron Pierre de Coubertin laid the foundation for the modern Olympic Games. The International Olympic Committee (IOC) was set up that year to restore the Olympic Games and as a result, the first modern-day Olympic Games were organized in Athens in 1896. This, and international competitions that followed, even further increased the need for the adoption of binding rules for the regulation of increasingly complex legal issues related to sports.

\subsection{Origins of organised sports in Slovenia}

Like elsewhere, sports activities have been carried out in the territory of Slovenia throughout history (e. g. hunting, horseback riding, shooting ...). However, an important milestone for the development of sports in Slovenia is certainly the year 1869, when the Austrian state law on primary education was adopted in Vienna, which introduced mandatory physical exercise in primary schools. The first teacher for physical exercise in Slovenia was a Croat Štefan Mandič (1813 - 1880), while the first Slovenian teacher was Fran Brunet. The introduction of physical exercise in schools was welcomed by young people, as they considered it something new and interesting, an activity that offered a more diverse and fulfilling life. Nevertheless, it is worth noting that physical exercise was initially mandatory only for the boys and that it became a mandatory part of schooling for girls only in 1901 (Petrović, Doupona Topič \& Petrovič, 2006).

Following the model of Czech Sokol (Falcon), the Southern Falcon (Južni Sokol) was founded in 1863 as the first gymnastic society in Slovenia. Initially, the organisation encountered problems because of the unequal treatment and a strong opposition from the German population, but it got a stronger foothold at the turn of the century, which is largely due to the efforts of Dr. Viktor Murnik (1874 - 1964). As a result of the rapid expansion of the so-called falconry (sokolstvo), 115 different Falcon societies were already established in Slovenia by 1913. In the meantime, a parallel organisation, known as the Eagle ( Orel), has also emerged, but has never been able to reach the popularity and importance of the Falcons (Petrović, Doupona Topič \& Petrovič, 2006; Mikša, 2010). 
The first sports club in Slovenia was a cycling club, which was established in Ljubljana in 1887. It was followed by a mountaineering society in 1893 and a football club Nafta (as the first football club established in Slovenian territory) in 1903. The first official football match in Slovenia was organised in 1911, between two Ljubljana football clubs: Ilirija, which was founded in 1911, and Hermes, which was founded in 1910 and mainly consisted of students. The first international football match was played on 23 June 1921 between Slovenia and France, at the Ilirija football stadium (T. D. L., 2015). In Maribor, the first sports club was founded in 1900. Its members were active in gymnastics, bowling, shooting, cycling and tennis (Petrović, Doupona Topič \& Petrovič, 2006). Further development of sports organisations (for more, see for example Mikša, 2010) led to an increased need for systematic legal solution and regulation of sports activities, which in turn led to the adoption of legislation related to sports law, first in Yugoslavia (e.g. Act on chivalric sports organisations of 1935) and later in the Republic of Slovenia (Sečen, 2019).

\subsection{Sports law in Slovenia}

Sports and law developed separately, both in response to the needs of society. It is therefore not surprising that both social phenomena (law and sport) came together under the auspices of sports law. Initially, some doubts were raised as to whether it was at all possible to speak of sports law as an independent legal discipline, since certain areas were perfectly covered by the law of obligations and criminal law. The idea of sports law as a special legal discipline was particularly encouraged following the Bosman case (see C-415/93 - Union royale belge des sociétés de football association and Others $v$ Bosman and Others). Therefore, there is no longer any doubt today, with sports law being widely recognized. It has shaped its own priority areas and dictated the need for such legal professionals. Sports law thus combines several legal disciplines, as it covers areas such as contract, tax, labour, competition, civil and criminal law. In recent decades, the occurrence of sport in the area of commercial law has been particularly noticeable, with the sports industry today being a well-designed system that generates an incredible amount of money (SK \& Ganotra, 2018). A rapid development of specific legislation, as well as case law, was also noted both at the national (including Slovenian) and international levels (Davis, 2001, pp. 211-244).

A special feature of sports law is that it can exist even without a specific law (lex specialis). Specific provisions of other legal acts may relate to or may be applied to sports, and thus form sports law (Kačer, Kačer \& Čizmić In: Kačer, 2019, p. 19). Slovenia is one of the countries with a framework sports act, which sets basic requirements for the organisation and performance of sports activities, whereas other issues can be solved by applying general provisions from Obligations Code, Criminal Code and other fundamental acts. In Slovenia a special legal branch of sport law is not well-developed, and dilemmas that arise in relation to sports are usually discussed separately, within each individual area of law. The article will 
present the historical development of framework sports act and some of the most important general acts that can also be applied to deal with sports-related issues.

\section{SPORTS ACT}

Sports Act (Zakon o športu, hereinafter: ZSpo), which came into force on 5 April 1998, was the first framework act regulating the organisation and some other aspects of sports activity in Slovenia. It granted the state and local communities the authority (and responsibility) to pursue public interest in sports and established the necessary framework; including the national programme of sport (which was then adopted for the period of 2000-2010) and annual sports programmes, the council of experts, public institutes for sport and sports inspection. ZSpo also determined necessary qualifications for the work of both expert professionals and individuals involved in sports, as well as the requirements to obtain the title of top-level athletes and some special rights accompanying this title. Furthermore, it determined the basic safety requirements for sports events, including the prohibition of the use of any pyrotechnic or other equipment by which the safety of the athletes and the spectators might be at risk and the restriction of access to a sports event to any person under the influence of alcohol. The liability for the security of all participants and spectators was placed on the organisers of sports events, who were also required to provide emergency medical assistance. The provisions of ZSpo were intended to represent basic legal grounds for the implementation of sports programmes, which is why they were mainly set in broad terms and were further complemented by other legal acts, by-laws, as well as autonomous rules of sports organisations.

ZSpo of 1998 doubtlessly contributed to a more comprehensive approach to the organisation and implementation of sports activities. According to the explanatory text accompanying the Proposal for the new Sports Act (Proposal of 23 December 2016), the measures adopted by the state and local communities on the basis of the national programme for 2000-2010 contributed significantly to a comprehensive growth and quality development of sport in the RS. The professionalism of working with children and young people has increased, infrastructural conditions for the exercise of sports activities facilitated the construction of a network of sports surfaces, a system of education and training of professional staff in sports has been established, and a significant progress has been detected in scientific and research activity in sport. However, the representatives of sports organisations pointed out some shortcomings that required further attention, which were further confirmed by the analysis conducted in 2006 by the Ministry of Education and Sport. The most pressing issues were identified in regard to the health care of athletes, personal development of top-level athletes, rights arising from the status of coaches, developing and promoting sports activities of children and young people with special needs and sports activities for disabled people and lack of adequate training infrastructures for some disciplines (for more details, see Proposal of 23 December 2016). 
With these shortcomings in mind, a new Resolution on the National Programme of Sports of the Republic of Slovenia 2014-2023 (hereinafter: the Resolution) was adopted by the National Assembly of the RS in April 2014. The Resolution pursues the vision that the sport should remain an important part of our nation's culture and to become and remain a necessary part of each person's healthy and positive lifestyle, and provides seven sets of measures intended to obtain this goal. Measures, which are explained in great details, are grouped into the following sets: (1) sports programmes (substantial basis for sports); (2) sports facilities and areas for sports in nature (material basis for sports); (3) developmental activities in sport (support for proper and safe performance of sports activities for all individuals); (4) organisation of sport (ensuring competitiveness and transparency of the operation of sports organisations); (5) sports events and the promotion of sport (enhancing the promotion of sport and generating economic and social benefits); (6) social and environmental responsibility in sport (providing an encouraging sustainable environment for sport development); and (7) support mechanisms for sport (a stimulating social environment for the development of sport and the prevention of abuse in sport). In order to fulfil the aims set out in the Resolution and to implement the necessary measures, a proper legislation had to be adopted, which is why in May 2014, an interdepartmental working group was established within the Ministry of Education and Sport to draft a new Sports Act that would tackle these issues.

The new Sports Act (hereinafter: ZŠpo-1) was adopted on 30 May 2017 and came into force on 24 June 2017. ZŠpo-1 sets out the public interest in the field of sport, mechanisms for serving said public interest, responsible authorities and the conditions for carrying out professional work in sport, the rights of athletes, public sports facilities and outdoor natural sports grounds, sporting events, and databases and supervision in the field of sport (Article 1 of ZŠpo-1). Mostly, ZŠpo1 addressed the same contents as previous ZŠpo, but amended or supplemented the provisions where necessary. However, there are several important changes that are worth explaining in more details:

\section{A) Definition of athletes and their rights:}

The definition of an athlete is expanded and now includes any individual who is registered in accordance with requirements under ZŠpo-1: they are at least 12 years old, are members of confirmed sports clubs, and have been entered in the records of registered and categorised athletes (the first paragraph of Article 32 of ZŠpo-1). This means that in addition to top-level athletes, recreationists are now also included. Once an athlete who is a Slovenian citizen reaches the age of 14, they are given the status of youth, national, prospective, international, or world- or Olympic-class athlete on the basis of their results achieved in competitions under an official competition system (the second paragraph of Article 32 of ZŠpo-1). Registered athletes are entitled to a number of benefits, including the adjustment of school and study obligations and examinations; adjustment in exercising the right to enrol in higher education institutions; preventive healthcare; the right to be absent 
from competition or training because of illness or injury; or, in exceptional cases, even an extraordinary pension (Article 35 of ZŠpo-1).

\section{B) Free transfer to another sports organisation:}

Athletes under the age of 15 are not required to pay any compensation for their transfer to another sports organisation. Athletes over the age of 15 may be required to pay compensation, but only if they have a written contract in which such compensation is determined and on the basis of which these athletes receive a payment amounting to at least the gross minimum wage in the RS. Even then, they are not required to pay compensation if the actual costs borne by the athlete for preparation and competitions under official competition systems exceed the payment they received (Article 34 of ZŠpo-1). Any conduct by a sports organisation or by a responsible person at sports organisation that violates these provisions shall be subject to a fine in the amount of up to 2000 EUR. Furthermore, any internal acts of sports organisations or contracts between the athlete and the sports organisation in violation of these provisions are considered null and void.

\section{C) The system of professional training for the acquisition of professional} qualifications in the field of sport:

The previous ZŠpo-1 did not specify the contents and the scope of training, the duration of training, the validity of programmes, who can conduct the training and how, who controls the implementation of training programmes, or levels of competence, which lead to a non-transparent situation with more than 350 different training programmes in 2015 (see also: Proposal of 23 December 2016). Under the Article 50 of ZŠpo-1, the Ministry of Education, Science and Sport is authorised to specify conditions for participation in training programmes, the criteria for transitioning between training programmes, the mandatory content of training programmes, the duration of individual training levels, the mandatory examination, the required references for lecturers of mandatory training contents, requirements for the head of a training programme, and the maximum price of training. ZŠpo1 also introduced a government-appointed accreditation commission, which is responsible for the proper accreditation of training programmes and acts as an expert, independent and autonomous body (Article 52 of ZŠpo-1). The state will thus have more control over the quality of qualifications required for the professional work in sport.

D) A uniform system for the distribution of public funds for the realisation of public interest:

ZŠpo-1 established a uniform system of financing which requires all providers that are financed from public funds to follow the structure and priorities defined by the national programme. A welcome change is introduced under Article 19 of ZŚpo-1, according to which the public tender procedure may be initiated prior to 
the adoption of national and local budgets (however, a decision on the selection cannot be issued before the adoption of the budget for the year in which the decision is issued). This provision will ensure a faster allocation of funds compared to the previous regulation, under which a late adoption of budgets has led to the end users receiving public funds only in the second half of the year, which has caused many problems for sports organisations at local and national level (see also: Proposal of 23 December 2016). Sports programme providers that have been selected for the implementation of annual sports programme at the national or local levels are now required to publish their calculation of the costs of the sports programme in order to ensure a greater transparency over the use of public funds. Furthermore, they are required to offer those sports programmes that are fully financed from public funds free of charge for the users, and proportionally reduce the costs in sports programmes that are partially co-financed from public funds (Article 31 of ZŠpo-1).

\section{E) Colours of national team uniforms:}

In order to promote the recognisability of the RS abroad, Article 36 of ZŠpo-1 introduces unified national colours of national team uniforms. All athletes who compete in official competitions for a Slovenian national team are required to wear their official sports uniforms, which shall be green, blue or white and bear the national coat-of-arms or the flag of the Republic of Slovenia (unless this is contrary to the rules of international sports federations).

\section{F) Control and supervision:}

ZŠpo-1 also introduced new bodies responsible for ensuring that its provisions are properly implemented and more possibilities for the participation of civil society and affected organisations. It sets out the responsibilities of the Sports Ombudsman, who safeguards the rights of athletes and professional sports workers (Article 66 of ZŠpo-1 and the following); the Council of Experts, which consist of 17 members appointed by the Government of the RS from among established experts and professional sports workers in the field of the sports programmes and which is responsible for the expert assistance in decision-making (Article 37 of ZŠpo-1 and the following); and the aforementioned accreditation commission. Furthermore, it specified more clearly supervisory bodies for each area of activity in sports, as well as their powers, and determined a comprehensive list of fines that can be imposed for the violation of ZŠpo-1 provisions.

During the public discussion before the adoption of the proposal for ZŠpo-1, more than 40 different organisations, associations, individuals and other entities submitted their comments, some of which were strongly critical of the new provisions (e.g. Slovenian Athletes Union complaints regarding the regulation of employment relationships with athletes and sports professionals). As ZŠpo-1 has not been in force for long, it is difficult to draw any particular conclusions regarding its benefits and shortcomings in practice. However, it is already clear that it managed 
to address certain recurring issues that occurred under the previous ZŠpo, so it can be considered an important step in the development of Slovenian sports law.

\section{SELECTED SPORTS LAW ISSUES}

\subsection{Liability for sports injuries}

\section{A) Criminal liability}

Injuries in sport are quite common; however, they are not treated as criminal offences, although a criminal offence of causing a minor bodily injury to another under Article 122 of the Slovenian Criminal Code (Kazenski zakonik - KZ-1) or causing a serious bodily injury to another under Article 123 of KZ-1 do cover any kind of bodily injury caused intentionally or out of negligence to the victim. Assaults and batteries that would render an athlete subject to criminal prosecution were they to occur away from the playing field are considered "part of the game" when they happen during the course of a sport (Standen, 2009). The reason injuries are not treated as a criminal offence is because sport is regarded as a generally useful and necessary activity in modern society (Bavcon, Šelih, Korošec, Ambrož \& Filipčič, 2014). Every sport has specific rules that the athletes must adhere to. Injuries occurring within the rules of the sport are regarded as accidents that are inevitable in sport and therefore do not deserve the status of criminally discarded behaviour (in English criminal law the doctrine of acting within the boundary of the rules will not automatically exculpate the perpetrator - unlawfulness of the violence must be determined independently of the question whether the attack was within the rules of the game. No rules or practice of any game can make lawful that which is unlawful by the law of the land. It must be proven whether an injury or death in sport was only an accident or wilful and intentional act of the perpetrator; McCutcheon, 1994). Intentional abuse of sport rules (tackling in football after the match has ended, physical assault in boxing after the final round has ended) in order to injure another would, however, be treated as a criminal offence. There is no reason to protect someone who intentionally injured another, since this is not an accident but an intentional act of the perpetrator with the goal to cause harm to another.

From the criminal law theory aspect, the reason why injuries in sport are not treated as illegal acts is because of the consent of the athletes. Body and physical integrity of a person is a typical disposable virtue, so there can be no doubt that anyone (except for children, mentally disabled persons or those with diminished mental capacity) can freely consent to cooperate in sport activity with full knowledge that sport activity could lead to potential injury. The consent of the injured party is a construct of modern criminal law which, when given appropriately (expressed voluntarily, unequivocally and in an appropriate formal form when needed), excludes the material unlawfulness of the criminal offence (Ashworth \& Holder, 2013). Jescheck \& Weigend (1996) define consent as a situation where the alleged 
victim or victim of a crime agrees with the disputed behaviour at the time of the execution. Prior consent of the injured therefore eliminates the need to criminally prosecute the person who caused the accident - the exception being an intentional abuse of sport rules with the goal to injure another (Novoselec \& Bojanić, 2013), or a case of gross carelessness in combination with disrespect of the rules of the game (Pajčić, 2009). Some argue that consent will also cease to exist where conduct in sport is extremely violent, and would objectively seem to lead to serious bodily harm. In such cases it will have exceeded any implied consent that a victim would have been permitted to give in the first place (Baxter, 2005; McCutcheon, 1994). While this may be true in ordinary contact sports (like football, basketball), it cannot be said for extreme fighting sports like boxing, Ultimate fighting Championship (UFC), kickboxing, where the participants are aware that serious injuries or even death can occur in the fighting ring, but nevertheless willingly cooperate in such activities. It is, however, clear that consent is invalid in cases of clear assaults outside of the rules of the game and that »consent defence « cannot be used in such cases (e.g. a hockey player intentionally striking the other with a hockey stick when leaving the penalty area, where the other player had no puck, as was the case in State v. Forbes in Minnesota; Binder, 1975). There is no court practice on the topic of sport injuries being treated as a criminal offence in Slovenia, since, as already discussed, sport injuries are treated as accidents that the participants in the game willingly consented to and since sport is treated as a generally useful and necessary activity, that is not in itself unlawful.

\section{B) Civil liability}

For the same reason, not all sports injuries may represent a basis for civil liability, and not every sport has the same standards of what is considered expected (e.g. in no-contact sports, such as running or swimming, rough (or any) bodily contacts are not a regular occurrence or an expected part of the game; Možina In: Bergant Rakovičević et al., 2008, p. 279). However, some general considerations need to be considered. First, an athlete who causes another athlete injury while following the rules of the game may not be held liable, as far as the injury resulted from the bodily contact that is allowed within the game. Second, even where the rules of the game have been breached, civil liability is not automatically implied (Stanec \& Milanović, 2019 , p. II). In order to hold an athlete liable for damage caused to another athlete in the course of the game, the court will first have to determine whether the injury was caused intentionally and whether it was caused by a severe violation of the rules of the game. In cases related to football injuries, the Supreme Court of the Republic of Slovenia has established a legal standard of due care expected from an average athlete (VSRS Judgement II Ips 227/2013; Frantar, 2004, 1611), and determined that the athlete may be liable for injuries resulting from an extreme improper conduct that is a result of excessive force, which cannot be expected by an average athlete (VSRS Judgement II Ips 108/2016; see also Možina In: Bergant Rakovičević et al., 2008, p. 277; Stanec \& Milanović, 2019, p. III). A special case is that of skiing, where Ski Area Safety Act (Zakon o varnosti na smučiščih - ZVSmuč-1) regulates, 
inter alia, basic safety rules for the use of skiing slopes and the responsibilities of skiers. The Supreme Court has already established a rule that skiers are liable if they caused damage as a result of the violation of ZVSmuč-1 (where their speed was not adjusted to the circumstances) (VSRS Judgement II Ips 214/2002; Možina In: Bergant Rakovičević et al., 2008, p. 281).

In addition to the liability of athletes for causing injury to another athlete in the course of the game, the liability of the organiser of a sports event should also be mentioned. Obligations Code (Obligacijski zakonik - OZ) regulates the organiser's liability in Article 157, which states that the organiser of an assembly of a large number of people in a closed area or in the open air shall be liable for damage caused by death or physical injury occurring because of the extraordinary circumstances that can arise in such opportunities, such as mass movement and general disorder. As opposed to a fault-based civil liability of the athletes, the organisers of sports events are therefore imposed with a strict liability for damage caused by death or physical injury; however, if death or physical injury has not occurred, or is not a result of extraordinary circumstances, the organisers' liability may only be faultbased (Možina In: Bergant Rakovičević et al., 2008, p. 306). In such case, the organiser may be relieved of liability if they manage to prove that they met the standard of due professional care and that the damage occurred even though they fulfilled all legal requirements regarding safety in sports events (Jadek Pensa In: Plavšak, 2003, p. 904; Plavšak, 2009, p. 588; Stanec \& Milanović, 2019, p. V).

\subsection{Employment status of athletes}

ZŠpo-1 tackled the issue of the employment of athletes by introducing new possibilities to conclude a contract of employment with different provisions than those laid down by the Employment Relationships Act (Zakon o delovnih razmerjih - ZDR-1) regarding rights, obligations and responsibilities arising from the employment relationship relating to the conditions and limitations of fixed-term employment; working time; the provision of breaks and rest periods; remuneration for work; disciplinary responsibility; and the termination of the employment contract (Article 59 of ZŠpo-1). Due to the special nature of work in sports, ZŠpo-1 also provided that notwithstanding the provisions of ZDR-1 regarding restrictions on concluding several fixed-term contracts for the performance of the same work (jointly no more than for two years, Article 55 of ZDR-1), an athlete may conclude successive fixed-term employment contracts with the same employer provided that the uninterrupted period of employment does not exceed ten years. An interruption of three months or less is not considered an interruption of the continuous period of employment (Article 60 of ZŠpo-1). Furthermore, the employment contract with an athlete may be concluded without a public notice of job vacancy (Article 61 of ZŠpo-1).

Despite the new possibility to consider a special nature of working in sports, sport clubs are generally not too keen on concluding contracts of employment with 
their athletes. Instead, they prefer to conclude a civil-law contract, with which the club enlists services of the athlete as a sole practitioner. In team sports, clubs hire athletes to compete for the club for a certain period (e.g. for a particular season). Such contracts are much easier to terminate, as the athletes are not protected by the provisions under ZDR-1, and are usually concluded for the benefit of the club, with the athlete at a disadvantage (Stanec \& Milanović, 2019, p. VI; Jagodic, 2014). If the club is not satisfied with the athlete's performance, they can thus unilaterally terminate the contract, without any serious financial repercussions. In Slovenia, many clubs include the so-called liquidated damages clause in the contract, with which the parties determine the amount of compensation for a one-sided termination of the contract without just cause. The amount is generally limited at a maximum amount of three monthly payments, which means that the athletes can find themselves in a difficult financial position, if the club terminates their contract in the middle of the season (Stanec \& Milanović, 2019, VI; see also p. Dušak, Fajdiga \& Stare, 2018).

If the athlete has not signed an employment contact and no compensation clause is determined in his civil-law contract, they are somewhat protected under the OZ and the provisions regulating work contract. According to Article 648 of OZ, the ordering party may withdraw from the contract at any time, but must pay the agreed payment to the contractor, which can be reduced by the costs not incurred by the contractor that would have been incurred had the contract not been terminated and also that which was earned elsewhere and that which the contractor failed to earn intentionally. Therefore, a club would have to compensate the athlete for terminating the contract before the agreed time with a full remaining value of the contract, minus what the athlete earned in another club during the same season (or failed to earn due to his own fault).

\subsection{Doping (criminal law aspect)}

Slovenia has adopted a very strict approach regarding plants or substances classified as illicit drugs. Unlawful production and trafficking of illicit drugs, illicit substances in sports, and precursors for the production of illicit drugs is a criminal offence under Article 186 of KZ-1 and Article 197 of KZ-1 with a high prison penalty (up to ten or eight years). Both articles deal not only with illicit drugs, but also with substances that are classified as illicit substances in sport. The key international regulation governing illicit substances in sports is the International Convention against Doping in Sports, which Slovenia ratified on 22 November 2007 with the Act ratifying the International Convention against Doping in Sport and which defines substances that are considered illicit substances in sport.

The above-mentioned articles of KZ-1 cover a broad spectrum of illegal activities related to illicit substances in sport. Article 186 of KZ-1 (Illicit production and trafficking of illicit drugs, illicit substances in sports and drug precursors) criminalises any kind of illegal production, processing, sale, or offer for sale, placing on the market, purchasing, storing, transferring, or otherwise placing illegal drugs or 
illicit substances in sport on the market with up to ten years of imprisonment. The sentence is higher (between three to fifteen years of imprisonment) if illegal drugs or illicit substances in sport are given to a minor, a mentally ill person, a person with a temporary mental disability, a severe mental retardation or a person in the process of withdrawal from addiction or rehabilitation, or if the act is committed by a civil servant, a priest, a doctor, a social worker, a teacher or the educator abusing his position, which could be relevant for sport teachers of minors, who gave them illicit substances to enhance their sport activity.

Article 187 of KZ-1 (Enabling the use of illicit drugs or illicit substances in sports) criminalises with the punishment of up to eight years of imprisonment situations when the perpetrator induces another to use illicit drugs or illicit substances in sports, or gives them for use, or who makes available facilities for the use of illicit drugs or illicit substances in sports, or otherwise enables another to consume illicit drugs or illicit substances in sports. Sentence is higher (from one to twelve years) if the act is done against several persons, against a minor, a mentally ill person, a person with a temporary mental disorder, severe mental retardation or a person in the process of separation from addiction or rehabilitation, or in educational institutions, in their immediate vicinity, in prisons, in military units, in public establishments or at public events, or by a civil servant, clergyman, physician, social worker, teacher or educator abusing his position.

Criminal law repression in Slovenia is therefore very strict when it comes to illicit drugs or illicit substances in sport. A very important fact is that KZ-1 does not distinguish between hard drugs (heroin, cocaine, LSD ...) and illicit substances in sport. Distribution of the latter is not regarded as a lesser offence, at least not in the legal text. The actual sentence will, of course, be in the hands of a judge, who can decide the appropriate punishment for the committed act. This of course means that any kind of distribution of illicit substances in sport is treated as a serious criminal offence, and not only as a misdemeanour with a light monetary sentence. Penalties are even stricter if illicit substances in sport are given to minors under 18 years of age or if a teacher or an educator abuses his position, which could be common in sport (e.g. a coach giving illicit substances to the athletes, lying to them about the nature of the substances, so that they believe they are taking vitamins or legally approved food supplements).

The equalization of illicit drugs and illicit substances in sport seems rather extreme, since, in principle, illicit substances in sport do not cause serious addiction and do not have such a detrimental effect on the health of individuals as illicit drugs. One of the reasons for that is that illicit substances in sports are more often pharmaceutical products used in human medicine. Although Slovenia has adopted a Minister's Decree on the classification of illicit drugs that includes a list of all substances that are regarded as illicit drugs, there is no such list for illicit substances in sport. Therefore, the police, state prosecutors and the courts are using a list that is included in the International Convention against Doping in Sport. The Supreme court of Slovenia has already decided (VSRS Judgement I Ips 9415/2011-235 \& 
VSRS Judgement I Ips 73104/2010-101) that the use of such international convention for identifying illicit substances in sport does not violate the principle of legality in criminal law (Šepec, 2018).

Both criminal offences are classified under the title of crimes against human health. These consequences are similar to those of crimes against life and body, and include the danger of spreading the consequences to an indefinite circle of people; therefore, general safety of people is concerned. The legally protected interest of both offences is therefore public health, which is a public legal interest, meaning that the consent of the victim plays no legally relevant role. Therefore, the consent of the athlete who takes illicit substances in sport from his coach/doctor in order to achieve better results does not exculpate the coach/doctor from his criminal activity and the criminalisation under Articles 186 and 187 of KZ-1.

\subsection{Media rights in sport}

The media are means by which sport reaches its viewers. The most popular sports are the ones that most often appear on TV and on the news. We can say that we are witnessing the mediatisation of sport (Klatell \& Marcus, 1996). It is in the interest of the sport to be on the TV, and it is in the interest of the media to broadcast famous sport events. However, the nature and the scope of media reporting on a sports event is a matter of civil contract between two parties - the one organising an event (the organiser) and the media company wanting to broadcast the event (broadcasting organisation). The content of the contract are broadcasting rights (television rights, rights for TV broadcasting), where the parties agree what can be broadcasted, how, where, for how long, and of course how much one party will have to pay to the other. Of course, sports that are not very popular on TV (e.g. judo, badminton) will usually be happy if a TV company shows up at the event and is willing to broadcast or report on the event. In such cases, a verbal agreement will generally suffice, as the TV company will not be willing to pay for broadcasting the event, while the organiser will not have any demands towards the TV company, when they are already overjoyed that the TV is even willing to broadcast and report on the event. However, a completely different topic are major sport events where the public and TV companies have a huge interest on broadcasting these events, as there will be many viewers at home willing to watch the broadcast (e.g. Super Bowl, NHL, NBA playoffs in USA, UEFA Championship League in Europe, First Football League in Slovenia). Here, the situation shifts, and normally a written contract is signed between both parties, in which the organiser will demand some kind of monetary compensation for allowing the TV company to broadcast the event. There are no special legal provision for such contracts; therefore, only the general rules of civil law and the $\mathrm{OZ}$ will matter. In a way, a TV company therefore buys permission from the organiser to broadcast the event. Without the permission, a TV company cannot broadcast the sports event; however, it can still prepare a short reportage (up to 90 seconds), if the event is in public interest (major event). 
This right of TV companies is defined in the European Convention on Transfrontier Television (1989) that Slovenia signed in 1996, and in Article 74 of the Mass Media Act (Zakon o medijih). In such cases, the organiser can only charge the price of the entry fee to the TV company.

Without the permission, the organiser has the right to prohibit anyone from entering the sports event (even the TV company). This can be problematic if the event is conducted in the open and on public grounds (skiing competition on the mountain, marathon on public streets ...). In such cases, the organiser has the right to construct a fence around the event and to prevent anyone from jumping over the fence without buying the ticket for the event (Bergant Rakočević In: Bergant Rakočević et al., 2008). However, the organiser has no right to control the sky or private property (someone's house is directly above the event that is happening in the centre of the city). The organiser will also have no way of prohibiting a TV company from filming the event from a helicopter, or even a drone, which can be extremely problematic these days, when drones have become quite affordable for TV companies and can produce a high quality images. The use of drones in Slovenia is legally very vague; they can be used for personal use, whereas the use for commercial purposes or for filming is prohibited. However, only the police has the authorisation to shut down a drone that is being used for filming without consent of a sports event, and not the organiser.

It should be mentioned that the performance of athletes in the sporting event (football match, badminton tournament ...) is not regarded as a copyright of the athletes or of the organiser of the event in accordance with the Copyright and Related Rights Act (Zakon o avtorski in sorodnih pravicah), although some sports events come very close to art plays that normally are protected (e.g. figure skating, gymnastic choreography ...). The athletes also cannot demand any kind of monetary compensation from the TV company that broadcasts the event or even in a way prohibit that their face is broadcasted on the TV. They have already consented to potential breaches of their privacy at the competition that include their appearance in the TV broadcast. Their consent is presumed due to them appearing in the competition, signing the entry contract or paying the entry fee. However, the athletes have not consented to the use of their image for advertising or commercial purposes - for such purposes an individual contract must be made between the athlete and his sponsor. It is also possible that the club the athlete is performing for has a sponsorship contract with a certain company that also legally binds the athlete, who is then compensated by the club.

\section{CONCLUSIONS}

Being one of the countries with a special framework act on the organisation of sports, Slovenia has adopted a systematic approach to the regulation of basic aspects of sports activities. However, as ZŠpo-1 focuses on organisational and 
financial conditions, most issues related to the sports law remain regulated in general legislation (e.g. criminal law, law of obligations, labour law, copyright law, etc.). While some areas are well covered by these general acts, it remains clear that more attention should be paid to specific characteristics of sports when drafting legislation. Therefore, many issues in Slovenian sports law are yet to be solved, for example, those regarding employment in sports, contracts with sports agents, sports disputes, sports marketing and sponsors, athletes' personal rights, etc. With a continuous developments of all these areas, there is no doubt that further steps will have to be taken to ensure proper legal safety for everyone involved in sports activities.

\section{REFERENCES}

1. Ashworth, A. \& Holder, J. (2013). Principles of criminal law ( $7^{\text {th }}$ ed.). Oxford: Oxford University Press.

2. Bavcon, L., Šelih, A., Korošec, D., Ambrož, M. i Filipčič, K. (2009). Kazensko pravo, splošni del ( $6^{\text {th }} e d$.). Ljubljana: Uradni list Republike Slovenije.

3. Baxter, A. (2005). Hockey Violence: The Canadian Criminal Code and Professional Hockey. Manitoba Law Journal 2(31), pp. 281-299.

4. Bergant Rakočević, V., Ilešič, M., Grilc, P., Podobnik, K., Vlahek, A., Levovnik, J., Jagodic. T., Možina, D. \& Gornik, M. (2008). Šport \& Pravo. Ljubljana: GV Založba.

5. Binder, L. R. (1975). The Consent Defense: Sports, Violence, and the Criminal Law. American Criminal Law Review 2(13), pp. 235-248.

6. Court of Justice of the EU. C-415/93. Union royale belge des sociétés de football association and Others v Bosman and Others. 15. 12. 1995.

7. Davis, T. (2001). What is Sports Law?, 11 Marq. SportsL. Rev., pp. $211-244$.

8. Dušak, M., Fajdiga, M., \& Stare, K. (2018). Ali novi Zakon o športu spodkopava temeljna načela delovne zakonodaje. Pravna praksa, 30-31/2018, pp. II-VII.

9. European Convention on Transfrontier Television, Council of Europe, ETS No. 132, 1989. Accessed: https://www.coe.int/en/web/conventions/full-list//conventions/ treaty/132 (22.12.2019).

10. Frantar, T. (2004). Odškodninska odgovornost v športu. Podjetje in delo, 6-7/2004, pp. 1607-1617.

11. International Convention against Doping in Sport, UNESCO, Oct. 19, 2005. Accessed: http://portal.unesco.org/en/ev.php-URL_ID=31037\&URL_DO=DO_TOPIC\&URL_ SECTION=201.html (22.12.2019).

12. Jagodic, T. (2014). Pogodbena razmerja v športu. Podjetje in delo, 6-7/2014, pp. 1618-1630.

13. Jescheck, H. H. \& Weigend, T. (1996). Lehrbuch des Strafrechts, allgemeiner Teil (5th ed.). Berlin: Duncker \& Humblot.

14. Kačer, H. (ed.). (2019). Sportsko pravo. Split: Sveučilište u Splitu. 
15. Kazenski zakonik - Criminal Code (KZ-1). Official Gazette of the Republic of Slovenia, no. 50/12 - official consolidated versions, 6/16 - popr., 54/15, 38/16 and 27/17.

16. Klatell, D. A. \& Marcus, N. (1996). Inside Big Time Sports. New York: Master Media Limited.

17. McCutcheon, J. P. (1994). Sports Violence, Consent and the Criminal Law. Northern Ireland Legal Quarterly 45, pp. 267-284.

18. Mikša, P. (2010). Šport na Slovenskem. In: Macura, D., Doupona Topič, M. \& Mekinda, B. (ed.) (2010). Statusna vprašanja slovenskega športa. Ljubljana: Univerza v Ljubljani, Fakulteta za šport, pp. 139-150.

19. Nanev, Lazar. (2013). Sports Law as an Independent Branch of Law. Balkan Social Science Review, Vol. 2, 167-187.

20. Novoselec, P. \& Bojanić, I. (2013). Opći dio kaznenog prava. Zagreb: Pravni fakultet sveučilišta u Zagrebu.

21. Obligacijski zakonik - Obligations Code (OZ). Official Gazette of the Republic of Slovenia, no. 97/07 - official consolidated version, 64/16 - odl. US and 20/18 OROZ631.

22. Pajčić, M. (2009). Kazneno djelo tjelesne ozljede počinjen tijekom sportskog natjecanja. Hrvatska pravna revija 9 (5), pp. 88-97.

23. Petrović, K., Doupona Topič, M. \& Petrovič, R. (2006). Šport in družba. Ljubljana: Fakulteta za šport.

24. Plavšak, N. et al. (2003). Obligacijski zakonik s komentarjem, prva knjiga. Ljubljana: GV Založba.

25. Plavšak, N. et al. (2009). Obligacijsko pravo, splošni del. Ljubljana: GV založba.

26. Predlog Zakona o športu - Proposal for the Sports Act of 23 December 2016. EVA: 2013-3330-0161.

27. Resolucija o Nacionalnem programu športa v Republiki Sloveniji za obdobje 20142023 - Resolution on the National Programme of Sport of the Republic of Slovenia 2014-2023 (ReNPŠ14-23). Official Gazette of the Republic of Slovenia, no. 26/14.

28. Sečen, E. (2019). Zgodovinska fronta: naše športne organizacije so amaterske in bodo takšne tudi ostale. Dnevnik 23.2.2019. Accessed: https://www.dnevnik. si/1042874295 (22.12.2019).

29. SK, G.\& Ganotra, S.(2018). Worldwide: Global Overview of The Sports Law. Accessed: <http://www.mondaq.com/x/684982/Sport/Global+Overview+of+the+Sports+Law> (17.12.2019).

30. Standen, J. (2009). The Manly Sports: The Problematic Use of Criminal Law to Regulate Sports Violence. Journal of Criminal Law and Criminology 3 (99), pp. 619-642.

31. Stanec, Š. \& Milanović, L. (2019). Posebnosti športa v pravu. Pravna praksa, 3435/2019, pp. II-VII.

32. Stanković, N. (2015). Istorija sporta. Brčko: Europski univerzitet Brčko district. 
33. Supreme Court of the Republic of Slovenia, VSRS Judgement I Ips 73104/2010-101 of 27. 9. 2012.

34. Supreme Court of the Republic of Slovenia, VSRS Judgement I Ips 9415/2011-235 of 22. 12. 2015.

35. Supreme Court of the Republic of Slovenia, VSRS Judgement II Ips 108/2016 of 5. 1. 2017.

36. Supreme Court of the Republic of Slovenia, VSRS Judgement II Ips 214/2002 of 24. 4. 2003.

37. Supreme Court of the Republic of Slovenia, VSRS Judgement II Ips 227/2013 of 16. 7. 2015.

38. Šepec, M. (2018). Analiza in dileme kaznivega dejanja proizvodnje in prometa s prepovedanimi drogami. Pravnik: revija za pravno teorijo in prakso 1/2 (73), 101-133.

39. T. D. L. (2015). Prva tekma slovenske reprezentance. Accessed: https://snportal.si/ zgodovina/prva-tekma-slovenske-reprezentance (2.10.2019).

40. The State of Minnesota vs. David S. Forbes. Case No. 63280.

41. Uredba o razvrstitvi prepovedanih drog - Decree on the classification of illicit drugs. Official Gazette of the Republic of Slovenia, no. 45/14, 22/16, 14/17, 4/19, 69/19.

42. Zakon o avtorski in sorodnih pravicah - Copyright and Related Rights Act (ZASP). Official Gazette of the Republic of Slovenia, no. 16/07 - official consolidated text, 68/08, 110/13, 56/15, 63/16 - ZKUASP and 59/19.

43. Zakon o delovnih razmerjih - Employment Relationship Act (ZDR-1). Official Gazette of the Republic of Slovenia, no. 21/13, 78/13 - popr., 47/15 - ZZSDT, 33/16 - PZ-F, 52/16, 15/17 - odl. US and 22/19 - ZPosS.

44. Zakon o medijih - Mass Media Act (ZMed). Official Gazette of the Republic of Slovenia, no. 110/06 - official consolidated text, 36/08 - ZPOmK-1, 77/10 - ZSFCJA, 90/10 - odl. US, 87/11 - ZAvMS, 47/12, 47/15 - ZZSDT, 22/16, 39/16, 45/19 - odl. US and 67/19 - odl. US.

45. Zakon o ratifikaciji Mednarodne konvencije proti uporabi nedovoljenih snovi v športu (MKUNSŠ) - Act Ratifying the International Convention Against Doping in Sport. Official Gazette of the Republic of Slovenia - International Treaties, no. 15/07.

46. Zakon o športu - Sports Act (ZSpo). Official Gazette of the Republic of Slovenia, no. 22/98, 97/01 - ZSDP, 15/03 - ZOPA and 29/17 - ZŠpo-1)

47. Zakon o športu - Sports Act (ZŠpo-1). Official Gazette of the Republic of Slovenia, no. $29 / 17$ and $21 / 18-$ ZNOrg.

48. Zakon o varnosti na smučiščih - Ski Area Safety Act (ZVSmuč-1). Official Gazette of the Republic of Slovenia, no. 44/16. 


\section{RAZVITAK SLOVENSKOG SPORTSKOG PRAVA}

U članku autori se bave temom razvoja prava sporta u Republici Sloveniji, s povijesne i analitičke perspektive. Nedavno je u Sloveniji primljen novi Zakon o sportu (ZŠpo-1), koji je zamijenio raniji i pomalo zastarjeli Zakon o sportu (ZSpo). Ovaj okvirni akt regulira osnovne zahtjeve organizacije i provođenja sportskih aktivnosti. Članak uključuje prezentaciju najvažnijih promjena koje utječu na organizaciju sporta u Sloveniji. Ostala pitanja koja se odnose na područje prava sporta općenito se mogu riješiti primjenom općih odredaba (npr. zakona o obveznim odnosima, kaznenog zakonika i drugih temeljnih zakona). Uz povijesni razvoj zakona o sportu, u članku se nalazi i analiza nekih najvažnijih općih akata koji se mogu primijeniti na pitanja vezana uz sport.

Ključne riječi: sportsko pravo, organizacija sportskih aktivnosti, odgovornost za sportske povrede, doping, medijska prava 